\title{
The Dynamics of English Use by Senior High School Students at Mengwi Sub-district, Badung Regency
}

\author{
I Nyoman Muliana $^{1}$, Anak Agung Gede Suarjaya ${ }^{2}$ \\ inyomanmulianabali@gmail.com ${ }^{1}$, agungsuarjaya@gmail.com² \\ Warmadewa University, Bali, Indonesia
}

\begin{abstract}
This paper is written based on a research on the the use of English by high school students in Kecamatan Mengwi, Badung Regency. The students have learnt the language about for twelve years since they were at their primary schools. The problems of the research are the forms of the dynamics of the use of English by the senior school students in Kecamatan Mengwi, Badung Regency and the factors causing the dynamics of the use of English by the senior school students in Kecamatan Mengwi, Badung Regency.The result of the research shows that the the dynamics of the use of English by the senior school students in Kecamatan Mengwi, Badung Regency are found in the use of vocabularies, verbs, adverbs, preposistions, sentence structures, and tenses. The factors causing the dynamics of the use of English by the senior school students in Kecamatan Mengwi, Badung Regency are language attitude, first language, and ignorance of English norms.
\end{abstract}

Keywords: dynamics, use, English, senior school students

\section{Introduction}

English is one of the languages that has become an international language. International language means that a language that is used as measn of communications among nations. English can be an international language because many countries use it as their first and official language. In many countries English is also used as lingua francas. The countries are spreading in all parts of the world. Most countries using Englsih for the purposes are the ones with big populations. In other countries English is used for different purposes such as education, business, tourism, etc. That is why people of the countries are in competitions to learn English. They want to be able to master the language in order that they participate more and better in many fields of their lives. As in education, books and other sources of sciences are mostly written in English. In business the need of using English is lamost the same as in education. Businesses such as in this era has been made by people from different countries that certainly requires an ideal means for their communications. The need of English cannot be avoided in tourism since this sector is the most obvious sector requiring people involving in it to be able to use English. Tourism sector is shown by the movement of people from one area to the others or one country to the others so that the mastery of English is obviously needed in the sector. 
Learning or using English is influenced by different factors. One of them is language attitude. It can be said that he factor can be the main factor in the pcocess of learning English. Language attitude is one's condition to a language and it is realised in the aspects. They are cognitive, affective, and conative aspects. The cognitive aspect of language attitutude is about people who can have certain vision to a language, they can find it in various conditions; an easy/a difficult language, a good/bad language, etc. Affective aspect is related to people's feeling toward a language. People may feel that they are happy/unhappy or like/dislike a language. The conative aspect of language attitude is about people's behaviour in using a language. People can decide to use or not to use the language correctly. Such conditions of language attitude also become phenomena found at the senior high school students in Mengwi District, Badung Regency.

\section{Methos of the Research}

This research on the the dynamics of the use of English by the senior school students in Kecamatan Mengwi, Badung Regency was conducted at 3 senior high schools in the district. The schools are Sekolah Menengah Atas Negeri 1 Mengwi, Sekolah Menengah Kejuruan Pariwisata Mengwitani, and Sekolah Menengah Atas Negeri 2 Mengwi. The method in collecting data applied was in two forms, they are assignment and observation that were paplied one by one. In assignment method, the students were given assignment to make short essyas in English. The essays were with eassy topics with consideration that the students were able to develop their writing abilities, both lexically and grammatically. They had to do the essays in 45 minutes in their classrooms. After the assignment methods, the data were also collected with observation method to find out the language attitude of the students in doing their essyas.

\section{Result and Discussion}

Based on data obtained from the research subjects, there is a dynamic use of English conducted by high school students in Mengwi District, Badung Regency. The 5 types of dynamics in using English can be categorized into 5 types, namely the dynamics of the use of words, sentence structure, tenses, prepositions, and English functions. Each form of dynamics of use can be discussed one by one in the following sections.

\subsection{The Use of Vocabularies}

Problems of using vocabularies are very obvious to those who are at the period of learning English as a foreign language. Such phenomena can also be found at the students of senior high school in Kecamatan Mengwi, Badung Regency as shownin the following data.

1. His person does not want to lose.

2. I school at senior high school in Mengwi.

Sentence 1 shows the inappropriate use of the word "person". The use of the word seems as direct translation of Indonesian word orang that in some context can be translated as "person" in English. The use of "orang" in Indonesian can be seen in the sentence with a context of definite person as in "orangnya" that literally means "the person" in English. That is why the word "person" is used the sentence that results inappropriateness. The appropriate 
sentence should be "He does not want to lose". Sentence 2 shows inappropriateness of the use of the word "school". The use of the word seems to be the case as in data 1 that the student made direct translation from the Indonesian word "sekolah" to express the message in the sentence. In Indonesian language, the context of the message is expressed with a sentence "Saya sekolah di sekolah menengah atas di Mengwi". This sentence having the word "sekolah" was directly translated into "school" and was also used in the English sentence so it becomes "I school at high senior in Mengwi" and it certainly becomes inappropriate in the English sentence. The sentence with the context should be "I go to a senior school in Mengwi".

\subsection{The Use of Verb}

Verb is an important element in English sentence. Its use in the sentence must done with some rules such as adaptation with the subject and the context of the sentence. Such rule of the use of verb in English certainly confuse learners especially the speakers of languages that are different from English as made by the students of senior high school in Kecamatan Mengwi, Badung Regency as shownin the following data.

1. They have many fans (data 9).

2. I'm take a bath (data 15).

Sentence 1 "They has many fans" shows the use of inappropriate verb "has". The use of the verb "has" in the sentence must be adapted with the subject of the sentence "they". The inappropriateness can occur because the student does not have such rule of the use of verb in his language. Both Balinese and Indonesian languages dot have such rule to use verb in the sentence with adaptations to the subject of the sentence so that such mistakes can be common things for Balinese and Indonesian speakers. Sentence 2 "I'm take a bath" also shows inappropriateness of the verb. The sentence uses the verb "am take" showing there is not any consistency to the context of the sentence. There are some possible forms of the verbs that can be used in the sentence, such as "take" and "am taking", etc. but, when the sentence is related to the context of the essay made by the student showing daily activity, the verb should be "take". The mistake of the use of the verb "am take" by the student in the sentence is certainly caused by the relation of the use of verb in the context in English sentence. Such kind of rule cannot be found in the languages of the student, such as Balinese and Indonesian languages.

\subsection{The Use of Adverb}

In English adverb has function to fill the element of adverbial in the sentence. One of the adverbs in English is "very" that has function to modify adjective. This form of adverb often confuses most speakers of Balinese and Inonesia languages as what the students did in their essays because in that languages they do not have the use of adverb "very" as in English. It canbe seen in the following data.

1. ... a man that is handsome and very love him. (data 7)

2. If they very desire Raina (data 32)

Both sentences above have inappropriate use of adverb "very". As its rule, the adverb must be used before adjective or adverb and that why its uses in the sentences above are 
inappropriate. In sentence 1, "very" is used before verb "love" and in sentence 2 it is used before the verb "desire". The use of "very" in such position can be because the student followed the use of the adverb "very" in his Indonesian rule. In Indonesian language, the adverb "very" means "sangat" that is used either before adjective and very, such as in "sangat besar" meaning "very big' and "sangat mengerti" meaning "very understand". The use of the adverb "very" before verb in English certainly cannot be accepted such as in the above sentences. The use of adverb "very" in that context of the sentences should be as in the following sentences.

1. ... a man that is very handsome and loves him very much.

2. If they desire Rahina very much.

\subsection{The Use of Preposistion}

Prepostion in English has many forms. They are used before nouns to show place and time. Some forms of the prepositions are clear to the learners of English as second or foreign language. However, some of them are also difficult for the senior high school students Mengwi District, Badung Regency as seen in the following data.

1. We go to home by plane.

2. She life at Buleleng.

The senior high school students Mengwi District, Badung Regency made mistakes in using prepositions in their essays. Most prepositions that are difficult for them to use are the single prepositions, such at, in, on, and to as shown in the sentences above. In sentence 1 the student made mistake in using the preposition "to" that is not needed in the sentence. The sentence does not need any preposition because it states a context of the verb "go" and noun "home". The combination of the two words does not take any preposition even though it is with the verb "go" meaning movement towards a place. The use of the preposition "to" in the sentence by the student can be caused by his general understanding to the use of the verb "go" that must be followed by preposistion "to". In sentence 2 there is also a mistake made by the student in using the preposition. There he used the preposition "at" before the noun "Buleleng". Buleleng that requires preposition "in".

\subsection{The Use of Sentence Structure}

English sentence/clause has structure consisting of some obligartory elements. The obligatory elements are subject and verb. This kind of rule is neglected by the students of senior high school in Mengwi District, Badung as seen in the following data.

1. He very good.

2. I was spent my holiday at home.

Sentence 1 of the data on the use of sentence structure above is "He very good". This sentence is ungrammatical in accordance with rule of English sentence. As stated above, English sentence must have two minimum elements of subject and verb as its structure. It means that there is one element absent from the sentence. The element is the verb that must be between the subject "he" and the complement "very good" and requiring the verb "be" so that the sentence should be "He is very good". The absence of the verb in the sentence is obviously 
a form of influence from his Indonesian sentence structure. In that language sentence with composistion of subject and complement does not take any verb as in English structure. So, in stating the meaning as stated by sentence 1 above in Indonesian language will be "Ia sangat baik" which can be described as "ia" is the subject and "sangat baik" is the complement. This explanation can prove that the sentence "He very good" made by the student is obviously as the influence of his Indonesian sentence structure. Sentence 2 of the above data is "I was spent my holiday at home". This sentence uses passive sentence structure but its context and is positive so that there is no any consistency between the two of them, between the structure and the meaning. The inconsistency is caused by the ignorance of the student on the rule of the sentence structure, especially active and passive strutucre. Based on the context or the meaning he wanted to say, the student should make the sentence as "I spent my holiday at home".

\subsection{The Use of Tenses}

Tenses become the main characteristics of English language. The structure cannot be found in other languages especially in Indonesian so that there are certainly many difficulties and mistakes appear in the use of tenses. Such problems of the use of tenses are also found in the essays of the students of the senior high school in Mengwi District, Badung Regency that can be seen in the following data.

1. Then when I arrived home I take a nap.

2. I know her since I was kindergarten.

Sentence 1 of the above data "Then when I arrived home I take a nap" has inappropriate use of tenses. The sentence belongs to complex sentence that can be seen from the two clauses in it. The first clause is "Then when I arrived home: and the second clause is "I take a nap". As a complex sentence with two clauses, the sentence has two verbs filling each of the clauses. The verb in the first clause is " "arrived" and the verb in the second clause is "take". Seen from the context, the student wanted to show his daily activity in the essay. So, the use of the verbs do not match each others; the verb "arrived" is in the past form, meanwhile the other one that is "take" is in the present form. Dealing with the context of the essay, both verbs must be in their present forms, thaye are "arrive" and "take". And the sentence should be "Then when I arrive home I take a nap". The mistake made by the student in using the appropriate verbs in the sentence is caused by his poor understanding on the rule of using two verbs in a sentence. Besides that, the mistake can be caused by the influence of his Indonesian language that does not have any structure of tenses.

Sentence 2 of the above data is "I know her since I was kindergarten". This sentence is also a complex sentence that na be seen from the two clauses in it, they are; "I know her" as the main clause and "since I was kindergarten" as the dependent clause. The two clauses build the sentence and each of them has their own verb. In the first clause there is a verb "know" and the second clause has the verb "since I was kindergarten". Seen from the sentence as whole, the sentence expresses the meaning of something has happened or someone has done something since at one point of time in the past till the time of speaking. In English this meaning is stated with present perfect tense and therefore the adverd of time for this tense if "since" and "for". The adverb of time can be stated with an adverbial clause by using the word since, such as in the sentence 2 "since I was kindergarten" in the dependent clause. The tense in the dependent clause is simple past tense, and the tense in the main or the independent 
clause must be in present perfect tense. Seen from this rule, it means that the sentence 2 made by the student is mistaken bcause it is not used appropriate tense. The sentence should be "I have known her since I was kindergarten". The mistake of the tense in the sentence made by the student can be influenced by his poor understanding on the tense especially the tense for stating the meaning as in sentence 2 above.

\subsection{Factors Causing the Dynamics of the Use of English by the Students of Senior High School in Mengwi District, Badung Regency}

There are three factors which cause the dynamics of the use of English by the students of senior high school in Mengwi District, Badung regency. The three factors are language attitude, first language, and ignorance of English rules.

The main factor related to language attitude becomes the main factor causing in the the dynamics of the use of English by the students of senior high school in Mengwi District, Badung regency. It could be seen from the observation method in the research. In the observation it could be seen that most of the students looked very difficult in doing the essyas. Almost $90 \%$ of them took time over than 45 minutes to do their essays. Their respons after having instruction of the assignment also took quite long time to do their essays. It can be concluded that the students still have negative language attitude to English language. The influence of the first language also influence the dynamics of the use of English by the students of senior high school in Mengwi District, Badung regency. It can be seen from the mistakes found in the essays that have Indonesia language rules. Such kind of mistakes are common to the students as learners of English language so that in using it they applied translation process from their Indonesian into English. The last factor causing the dynamics of the use of English by the students of senior high school in Mengwi District, Badung regency is the ignorance of English rules.

\section{Conclusion}

There are some conclusions that can be taken from the analysis of the research. The conclusions are as the following.

1. The dynamics of the use of English by the students of senior high school in Mengwi District, Badung regency are in the forms of the uses of vocabularies, vebs, adverbs, prepositions, sentence structures, and tenses.

2. The dynamics of the use of English by the students of senior high school in Mengwi District, Badung regency are caused by language attitude to English, the first language of the students, and ignorance of English language rules.

\section{References}

[1] Appel, Rene dan Muysken, Pieter. Language Contact and Bilingualism. Great Britain : Hodder and Soughton Ltd. (1987)

[2] Aslinda dan Syafyahya, Leni. Pengantar Sosiolinguistik. Bandung: PT. Refika Aditama. (2007)

[3] Azar, B.S.,. Fundamentals of English Grammar Second Edition. Edisi Inggris-Indonesia. Jakarta : Binarupa Aksara. (1993) 
[4] Gunarwan, Hasim. "Sikap Subjektif terhadap Bahasa Indonesia Baku dan Non Baku : Sebuah Pengkajian Sikap Bahasa" dalam Kongres Bahasa Indonesia IV tahun 1985. Jakarta : Pusat Pembinaan dan Pengembangan Bahasa Departemen Pendidikan dan Kebudayaan. (1985)

[5] Holmes, Janet. An Introduction to Sosiolinguistics. London : Longman. (1992)

[6] Jendra, I Wayan. Dasar-Dasar Sosiolinguistik. Denpasar : Penerbit Ikayana. (1991)

[7] Sumarsono. Pemertahanan Bahasa Melayu Loloan. Jakarta : Pusat Bahasa. (1993)

[8] Suhardi, B. Sikap Bahasa suatu Telaah Eksploratif atas Sekelompok Sarjana dan Mahasiswa di Jakarta. Depok : Fakultas Sastra, Universitas Indonesia. (1996)

[9] Suteja, I Ketut. Sikap Bahasa Kelompok Mahasiswa Etnis Bali terhadap Pemakaian Bahasa Bali. Disertasi. Denpasar : Program Studi Doktor, Program Pascasarjana, Universitas Udayana. (2007)

[10] Thomas, Linda dan Wareing, Shan. Language, Society and Power. New York : Routledge. (1999) 